\title{
Parodon orinocensis (Bonilla et al., 1999) (Characiformes: Parodontidae): emendations and generic reallocation
}

\author{
Leonardo F. S. Ingenito ${ }^{1,}$, Carla S. Pavanelli ${ }^{2}$ and Francisco Provenzano ${ }^{3}$
}

During recent studies on Parodontidae, specimens of the Venezuelan species Parodon orinocensis (Bonilla, Machado-Allison, Silvera, Chernoff, López \& Lasso, 1999) were examined and a few incongruencies with the original description of the species were noted. Emendations to the descriptions of the jaw teeth and color pattern are presented. Three autapomorphies were also observed and are listed herein. The species is moved from genus Apareiodon to Parodon based on presence of dentary teeth.

Durante estudos recentes sobre Parodontidae, espécimes da espécie venezuelana Parodon orinocencis (Bonilla, MachadoAllison, Silvera, Chernoff, López \& Lasso, 1999) foram examinados e reconhecidas algumas incongruências na descrição original. Foram realizadas retificações relacionadas aos dentes das maxilas e ao padrão de coloração. Três autapomorfias foram observadas e são aqui listadas. Com base na presença de dentes no dentário a espécie é transferida do gênero Apareiodon para o gênero Parodon.

Key words: Freshwater fish, Neotropical, Ostariophysi, Río Orinoco basin, Taxonomy.

\section{Introduction}

Parodontidae Eigenmann, 1910 is a small characiform family composed by three currently valid genera, Parodon Valenciennes, 1849, Saccodon Kner, 1863 and Apareiodon Eigenmann, 1916, and 32 valid species (Pavanelli, 1999; Pavanelli, 2003; Pavanelli \& Britski, 2003; Ingenito \& Buckup, 2005; Pavanelli, 2006; Taphorn et al., 2008; Landoño-Burbano, 2011). The three genera are traditionally characterized by the variation of two characters: number of unbranched pectoralfin rays (one in Parodon and Apareiodon, and two in Saccodon), and absence of mandibullary teeth (in Apareiodon and Saccodon) (Eigenmann, 1916; Ingenito \& Buckup, 2005).

Up to latter last century, only one species of the genus Apareiodon (A. gransabana Starnes \& Schindler, 1993) and three from the genus Parodon (P. apolinari Myers, 1930, $P$. guyanensis Géry, 1960 and P. suborbitalis Valenciennes, 1849) were known from the río Orinoco basin, in Venezuela. However, Bonilla et al. (1999) described a second species of Apareiodon from that basin, A. orinocensis. Based on the classic tooth characterization of the parodontid genera, those authors allocated their new species to the genus Apareiodon, since the species was held to have an edentulous lower jaw. After examining extensive parodontid material from Venezuela, including the holotype (MBUCV-V 29170) and paratypes (MBUCV-V 26669) of A. orinocensis, we noted some incongruencies between the original description and the studied specimens. Such differences are herein presented.

\section{Material and Methods}

Analysis of A. orinocensis was based on 49 alcohol preserved museum specimens. Two specimens were cleared and stained (c\&s) according to Potthoff's (1984) methodology. Counts an measuremets follow Pavanelli \& Britski (2003) and Ingenito \& Buckup (2005). Morphological measurements were made point-to-point to the nearest $0.01 \mathrm{~mm}$ with electronic calipers on the left side of the specimens whenever possible.

\footnotetext{
${ }^{1}$ Universidade Federal do Espírito Santo, Programa de Pós-Graduação em Biodiversidade Tropical, Centro Universitário Norte do Espírito Santo, Departamento de Ciências Agrárias e Biológicas, Sala 15, Rodovia BR-101 Norte, Km 60, 29932-540 São Mateus, ES, Brazil. lfsi@uol.com.br

${ }^{2}$ Universidade Estadual de Maringá, Núcleo de Pesquisas em Limnologia, Ictiologia e Aquicultura (Nupélia), Av. Colombo, 5790, 87020900 Maringá, PR, Brazil. carlasp@nupelia.uem.br

${ }^{3}$ Universidad Central de Venezuela, Instituto de Zoología y Ecologia Tropical, Apartado 47058, Caracas 1041-A, Venezuela. francisco.provenzano@ciens.ucv.ve
} 
Number of observed teeth is presented in the text followed by their frequency in parenthesis. An asterisk indicates counts for the holotype. Standard length (SL) is presented after catalog numbers of the lots. All species from the family were examined except the recently described $P$. alfonsoi LondoñoBurbano, Román-Valencia \& Taphorn, 2011, P. atratoensis Londoño-Burbano, Román-Valencia \& Taphorn, 2011 and $P$. magdalenensis Londoño-Burbano, Román-Valencia \& Taphorn, 2011. Data from these three species were obtained exclusively from the original descriptions. Osteological nomenclature follows Roberts (1974a) and Schultze \& Arratia (1989). Institutional abbreviations are: AMNH, American Museum of Natural History, New York; CAS, California Academy of Sciences, San Francisco; IAvH - Instituto de Investigación de Recursos Biológicos Alexander von Humboldt, Villa de Leyva; INPA, Instituto Nacional de Pesquisas da Amazônia, Manaus; MBUCV, Museo de Biologia de la Universidad Central de Venezuela, Caracas; MCNG Museo de Ciencias Naturales de Guanare, Guanare; MCP, Museu de Ciências e Tecnologia, Pontifícia Universidade Católica do Rio Grande do Sul, Porto Alegre; MHNCI, Museu de História Natural Capão da Imbuia, Curitiba; MNRJ, Museu Nacional, Universidade Federal do Rio de Janeiro, Rio de Janeiro; MZUSP, Museu de Zoologia da Universidade de São Paulo, São Paulo; NUP, Coleção Ictiológica do Nupélia (Núcleo de Pesquisas em Limnologia, Ictiologia e Aquicultura da Universidade Estadual de Maringá) Maringá; USNM, National Museum of Natural History, Smithsonian Insitution, Washington D.C.

\section{Parodon orinocensis (Bonilla, Machado-Allison, Silvera, Chernoff, López \& Lasso, 1999), new combination Fig. 1}

Apareiodon orinocensis Bonilla et al., 1999:2 (original description; type locality: "Raudal Dimoshi, río Tabaro, BO”; holotype: MBUCV-V 29170; pictures of holotype and paratype). -Pavanelli, 2003: 43 (checklist). -Vari et al., 2009: 25, 67 (checklist and picture).

Type material examined. MBUCV-V 29170, holotype, 131.9 mm SL, Venezuela, Bolívar State, río Caura system, río Tabaro, Raudal Dimoshi, río Orinoco basin, 15 September 1993, A. MachadoAllison et al. MBUCV-V 26669, 4 of 6 paratypes, 111.6-121.1 mm $\mathrm{SL}$, same data as the holotype.

Non-type material examined. All from Venezuela. AMNH 233108, 11, 50.7-102.1 mm SL, Amazonas State, río Cuao, beach downstream of Raudal del Danto, 0502'39'N 67033'35'W, 10 March 2001; ANSP 185045, 4, 68.2-69.4 mm SL, Amazonas State, río Orinoco at Puerto Venado, $4.3 \mathrm{~km} \mathrm{~S}$ of Samariapo, $56.4 \mathrm{~km} \mathrm{SW}$ of Puerto Ayacucho, 26 February 2005; ANSP 185048, 3, 58.2-103.2 mm SL, Amazonas State, río Casiquiare drainage, río Siapa, Raudal de Gallineta, 142 km E of San Carlos de río Negro, 17 March 2005; ANSP 185087, 3, 63.1-67.6 mm SL, Amazonas State, río Casiquiare drainage, Caño Guama, right bank trib. río Siapa, above Raudales de Aracamuni and below Salto Sardinas, 16 March 2005; ANSP 185090, 4, 52.7-94.5 mm SL, Amazonas State, río Casiquiare drainage, río
Siapa, Raudales de Aracamuni, 154 km E of San Carlos de río Negro, 11 March 2005; FMNH 109916, 1, 60.0 mm SL, Bolívar State, río Caura, rapids at Paují, 549’40”N 64²4’22”W, 28 November 2000; FMNH 109917, 2, 58.0-60.0 mm SL, Bolívar State, río Caura, Playa Rocosa across from El Playón, 6¹9'43'”N 64³1'40’'W, 03 December 2000; MCNG 50127, 1, 87.1 mm SL, Amazonas State, río Parucito, río Venturari system, Raudales Salomón, 2.7 km NE of San Juan de Manapiare, río Orinoco basin, 16 April 2004; MBUCVV 24475, 5 of 19, 35.4-39.8 mm SL, 1 c\&s, 37.4 mm SL, Amazonas State, río Orinoco, Zamuro behind Puerto Ayacucho, 09 August 1984 (non-type material used in the original description); MBUCVV 30116, 7 of 9, 52.6-127.9 mm SL, 2 c\&s, A: 54.2 mm SL, B: 99.5 mm SL, Amazonas State, río Cuao, nearby Raudal del Danto, río Orinoco basin, 09 March 2001.

The first incongruence observed during our studies was the presence of mandibulary teeth on dentary bones. Bonilla et al. (1999) indicated that such teeth were absent in their new species, resulting in their allocating that species to the genus Apareiodon. Nevertheless, one (1), two (32*) or three (3) mandibulary teeth can be clearly observed. Under traditional concept of the genus Apareiodon, such information compels us to reallocate $A$. orinocensis to the genus Parodon.

Starnes \& Schindler (1993) stated five synapomorphies for the genus Apareiodon based on morphology of mouth bones. However, such characters where tested by Ingenito (2008) for all species of Parodontidae and reveled to be related to some species only or inapplicable as stated by those authors for many species of the family. If the propositions of Starnes \& Schindler (1993) were accepted, P. orinocensis should be kept in Apareiodon, what contradicts both the traditional Eigenmann's definition for the parodontids genera and the results obtained by Ingenito (2008).

Another incongruence of concern is the number of upper jaw teeth. Compared to the diagnosis supplied in the species' original description, which stated the presence of six premaxillary teeth, we found only four in all examined specimens, including types. Such a count is in agreement with all other Parodon and Apareiodon species, except $A$. agmatos Taphorn, López-Fernández \& Bernard, 2008, A. gransabana and $P$. guyanensis, which bear five premaxillary teeth. The maxillary bone bears two teeth, as in most parodontids, which is in agreement with the authors' statements.

Finally, the description of the longitudinal stripes presented by Bonilla et al. (1999) is not fully compatible with the color pattern observed by us and needs to be emended, as this is an important diagnostic character for species of Parodontidae. The coloration pattern of the flanks of $P$. orinocensis is composed of three longitudinal stripes and five to seven wide, vertical, dark bars situated between the mid-lateral longitudinal stripe and dorsal region. The midlateral stripe has ill-defined limits, forming a zigzag, and transverse bars do not extend below this feature. That zigzag shape was not noted in the original description and is a useful character that discriminates $P$. orinocensis from $P$. apolinari and $P$. caliensis Boulenger, 1895 (which have disconnected 


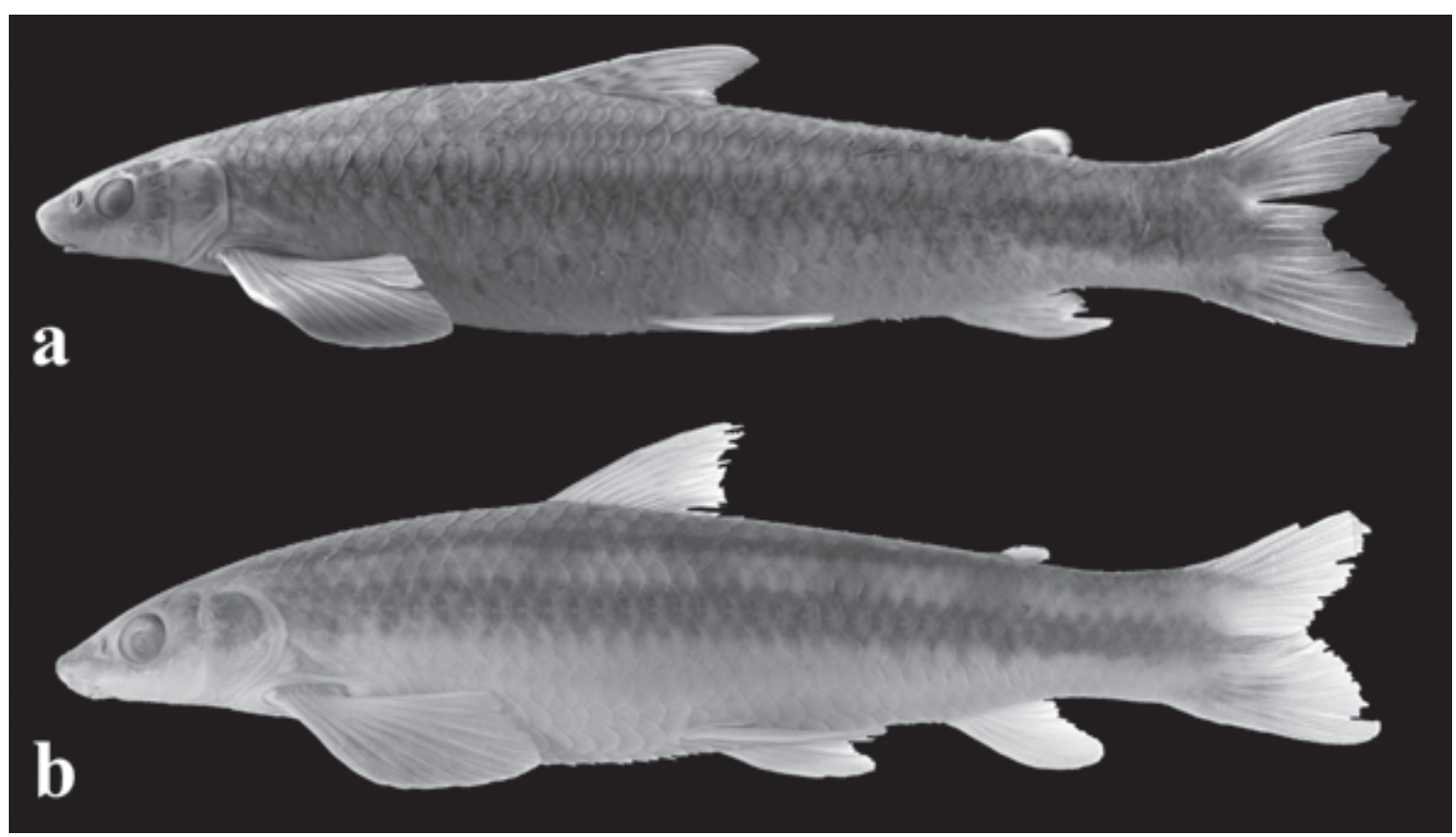

Fig. 1. Parodon orinocensis: (a) MBUCV-V 29170, holotype, $131.9 \mathrm{~mm}$ SL, Raudal Dimoshi (photo by Carlos do Nascimiento and Nadia Milani); (b) AMNH 233108, 99.4 mm SL, Raudal del Danto (photo by Sandra Raredon).

transverse bars instead of a mid-lateral stripe) and from $P$. guyanensis, P. moreirai Ingenito \& Buckup, 2005, P. pongoensis (Allen, 1942), and Apareiodon species (in which the mid-lateral stripe lacks dorsal or ventral projections). The mid-lateral stripe pattern found on $P$. orinocensis is also present in other congeners ( $P$. alfonsoi, $P$. atratoensis, $P$. bifasciatus Eigenmann, 1912, P. buckleyi Boulenger, 1887, $P$. carrikeri Fowler, 1940, P. hilarii Reinhardt, 1866, P. magdalenensis, P. nasus Kner, 1859, and $P$. suborbitalis). From these species $P$. orinocensis can be distinguished by its very pointed snout (versus rounded), and the strongly rounded cutting edges of the premaxillary teeth (versus straight or almost straight). Additionally, the three sympatric congeners of $P$. orinocensis from the Río Orinoco basin can be easily distinguished from it as follows: P. apolinari has longer supraocciptal process to isthmus distance (1.2-1.5 versus 1.61.9 times in HL), deeper body (3.4-4.1 versus 4.2-5.3 times in SL), and 36-38 lateral-line scales (versus 40-43); P. guyanensis has five premaxillary teeth (versus four) and distal one-third of dorsal fin dark (versus not dark); P. suborbitalis has 36 to 39 lateral-line scales (versus 40-43), larger adipose to anal-fin distance (5.0-5.9 versus 6.0-7.7 times in SL), and larger supraocciptal process to isthmus distance (1.0-1.5 versus 1.61.9 times in $\mathrm{HL}$ ).

The mid-lateral stripe of $P$. orinocensis may have welldefined dorsal and ventral margins (without zigzag projections) on caudal peduncle of some specimens. The zigzag limits of the mid-lateral stripe may not be noticeable in juvenile specimens (less than $50 \mathrm{~mm} \mathrm{SL}$ ), as shown in Fig. 1a of the original description, and specimens larger than $110 \mathrm{~mm}$
SL, as shown in Fig. 1b by Bonilla et al. (1999: 4). So we conclude that the authors probably based their color descriptions only on these two length classes.

A second inconspicuous longitudinal stripe is present between the mid-lateral stripe and dorsal region. This dorsolateral stripe was noted by Bonilla et al. (1999) and can be easily observed in Figure 3 from Bonilla et al. (1999: 5). This stripe is present in all parodontid species, except P. apolinari and $P$. caliensis. However, the dorsolateral stripe is often difficult to discern and may be obscured by dusky coloration of the dorsum of Parodontidae's species. The non-observation of such stripes in $P$. apolinari and $P$. caliensisi may be due to the faint color of the specimens we have studied.

At the region between main stripe and pectoral fin there is an inconspicuous dark ventrolateral stripe extending from cleithral area to region over anal fin. This stripe is separated by one scale row beneath the mid-lateral stripe, occupies about a half to one scale width and was not cited by Bonilla et al. (1999), even its being seen in their Fig. 1a (Bonilla et al., 1999: 4). The presence of a ventrolateral stripe also occurs in many species of Parodontidae, except on A. davisi Fowler, 1941, A. hasemani Eigenmann, 1916, A. ibitiensis Campos, 1944, A. itapicuruensis Eigenmann \& Henn, 1916, A. tigrinus Pavanelli \& Britski, 2003, P. apolinari, P. bifasciatus, P. caliensis, and P. guyanensis. Otherwise, A. agmatos and A. gransabana have multiple ventrolateral stripes. Based on inference from the original descriptions, this stripe also seems to be absent in P. alfonsoi, P. atratoensis and P. magdalenensis.

During our studies, we also discovered three autapomorphies for $P$. orinocensis. The first one is related to 


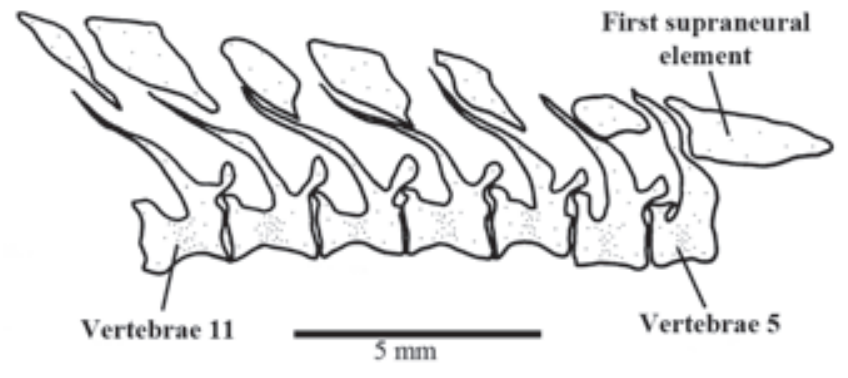

Fig. 2. Right view of vertebrae 5-11 of Parodon orinocensis, MBUCV-V 30116, 99.5 mm SL.

the form of the neural spines from vertebrae 5 to 16 or 17 . At this region the neural spines of $P$. orinocensis are strongly curved backward, a condition not observed in any other characiform species and most evident on the distal half of vertebrae 5 to 11 (Fig. 2). This character state was not observed in the juvenile specimen of $P$. orinocensis examined herein, and thus may develop late in the ontogeny of this species.

We also observed that $P$. orinocensis has the opening of the lower lateral posttemporal fossa very narrow as compared with other members of the family. This species also has complete fusion of hypurals I and II, a condition lacking in all other parodontids.

Comparative material. Parodontidae. Apareiodon affinis: MCP 11594, 09, 39.4-59.2mm SL, + 01 c\&s, 42.6mm SL, Argentina, Buenos Aires, Pdo. San Isidre, río de La Plata, en Náutica; lower rio Paraná basin. MNRJ 17042, 55, 69.0-81.0 mm SL, + 01 c\&s, 72.4 mm SL, Brazil, Minas Gerais State, Bom Sucesso, ribeirão da Babilônia, right tributary of rio Grande, upper rio Paraná basin. MNRJ 19906, 64.7-72.8 mm SL, + 01 c\&s, 71.56 mm SL, Brazil, Goiás State, Catalão, córrego Anta Gorda, left tributary of rio São Marcos, rio Paranaíba drainage, upper rio Paraná basin. Apareiodon agmatos: NUP 5950, paratypes, 3, 41.6-49.1 mm SL, + 01 c\&s, 42.0 mm SL, sandy beach and embayment on right bank of rio Mazaruni, upstream from village of Jawalla, rio Mazaruni basin, atlantic coastal drainage. Apareiodon argenteus: MZUSP 59615, paratype, 14 of 25, 49.5-79.2 mm SL, + 01 c\&s, 71.5 mm SL, Brazil, Goiás State, Minaçu, rio Tocantinzinho and affluents, rio Tocantins basin. Apareiodon cavalcante: MNRJ 12566, paratypes, 16, 37.4-55.6 mm SL, + 01 c\&s, A: 45.0 mm, B: 47.0 mm SL, Brazil, Goiás State, Cavalcante, ribeirão do Padre, rio Tocantins basin. Apareiodon davisi: MNRJ 4678, 154, 16.3-59.7 mm SL, + 02 c\&s, A: 44.2 mm, B: 42.6 mm SL, Brazil, Ceará State, Iguatu, rio Jaguaribe, atlantic coastal drainage. Apareiodon gransabana: MCNG 43343, 27, 49.1-89.4 mm SL, + 02 c\&s, A: 75.8 mm, B: 67.8 mm SL, Venezuela, Bolívar, Roscio, río Caroni drainage, río Orinoco basin. USNM 267917, paratypes, 08, 42.3-62.4 mm SL, + 01 c\&s, near 47 mm SL, Venezuela, Bolívar, La Gran Sabana, río Tarota, río Orinoco basin. Apareiodon hasemani: MNRJ 14212, 39, 18.6-56.8 mm SL, + 02 c\&s, A: 53.0 mm, B: 55.6 mm SL, Brazil, Minas Gerais State, Manga, rio São Francisco, rio São Francisco basin. Apareiodon ibitiensis: MNRJ 28093, 53, 73.2-103.8 mm SL, + 02 c\&s, A: 84.3 mm, B: 87.6 mm SL, Brazil, Minas Gerais State, Três Marias, riacho Frio, rio São
Francisco basin. Apareiodon itapicuruensis: MCP 17877, 09 of 19, 67.7-85.0 mm SL, + 01 c\&s, 72.8 mm SL, Brazil, Bahia State, rio Califórnia at rio Água Fria mouth, atlantic coastal drainage. MNRJ 21688, 21, 12.6-55.4 mm SL, + 01 c\&s, 60.6 mm SL; Brazil, Bahia State, Itaetê, rio Una, rio Paraguaçu basin, atlantic coastal drainage. Apareiodon machrisi: MCP 15966, 08 of 39, 62.4-74.4 mm SL, + 02 c\&s, A: 68.9 mm, B: $64.1 \mathrm{~mm}$ SL, Brazil, Goiás State, Niquelândia, ribeirão do Engenho, rio Tocantins basin. Apareiodon piracicabae: MNRJ 28155, 48, 67.2-91.6 mm SL, + 02 c\&s, A: 79.5 mm, B: 74.0 mm SL, Brazil, São Paulo State, Ipeúna, rio Passa Cinco, upper rio Paraná basin. Apareiodon tigrinus: MZUSP 59616, paratypes, 07 of 15, 26.861.9 mm SL, + 01 c\&s, 42.5 mm SL, Brazil, Goiás State, Santa Rita do Araguaia, córrego do Jacaré, rio Tocantins basin. Apareiodon vittatus: MHNCI 7141, 03 of 08, 98.8-122.0 mm SL, + 01 c\&s, 106.5 mm SL, Brazil, Paraná State, Nova Prata do Iguaçu, rio Iguaçu, rio Paraná basin. MNRJ 28445, 10, 91.4103.4 mm SL, + 01 c\&s, 94.0 mm SL, Brazil, Paraná State, Quedas do Iguaçu, Salto Osório reservoir, rio Iguaçu, rio Paraná basin. Apareiodon vladii: MNRJ 28202, 05, 87.4-100.5 mm SL, + 01 c\&s, 89.4 mm SL, Brazil, Paraná State, Nova Laranjeira, rio Piquiri, upper rio Paraná basin. Parodon apolinari: IAvH 3438, 04, 62.4-88.9 mm SL, + 01 c\&s, 68.3 mm SL, Colombia, Casanare, rios Unete, Cravo Sur y Tua, río Meta drainage, río Orinoco basin. MCNG 19773, 05 of 131, 52.7-93.4 mm SL, + 01 c\&s, 79.9 mm SL, Venezuela, Portuguesa, Guanare, río Las Marias, río Apure drainage, río Orinoco basin. Parodon bifasciatus: INPA 10926, 03, 83.1-98.6 mm SL, + 01 c\&s, 78.1 mm SL, Brazil, Roraima State, Mucajaí, rio Mucajaí, rio Branco basin. Parodon buckleyi: IAvH 6193, 01, 82.6 mm SL, + 01 c\&s, 121.6 mm SL, Colombia, Putumayo, Mocoa, río Rumiyaco, río Caquetá basin. Parodon caliensis: CAS 6767, 01, 66.4 mm SL, Colombia, Cauca, río Paila, río Magdalena basin. Parodon carrikeri: USNM 319292, 12, 94.3-150.2 mm SL, + 01 c\&s, 119.7 mm SL, Bolivia, Tarija, río Salinas, río Bermejo drainage, río Paraguay basin. Parodon guyanensis: MBUCV-V 31463, 02 of 37, 46.3-57.8 mm SL, + 01 c\&s, 58.0 mm SL, Venezuela, Bolívar, sector La Piña, poseción Los Monos, río Aro, río Orinoco basin. MCNG 18337, 04 de 25, 18.8-67.9 mm SL, + 01 c\&s, 61.0 mm SL, Venezuela, Bolívar, Heres, río Tocoma medio, río Caroni drainage, río Orinoco basin. Parodon hilarii: MCP 16939, 10, 41.3-75.2 mm SL, + 01 c\&s, 63.6 mm SL, Brazil, Minas Gerais State, rio Catitu, rio São Francisco basin. MNRJ 28082, 14, 84.3-120.2 mm SL, + 01 c\&s, 88.4 mm SL, Brazil, Minas Gerais State, Três Marias, rio São Francisco, rio São Francisco basin. Parodon moreirai: MNRJ 22207, paratypes, 03, 99.0-124.3 mm SL, + 01 c\&s, 115.4 mm SL, Brazil, São Paulo State, São Bento do Sapucaí, tributary of rio Grande, upper rio Paraná basin. Parodon nasus: MNRJ 28157, 66, 63.3-110.4 mm SL, + 02 c\&s, A: 94.1 mm, B: 77.6 mm SL, Brazil, São Paulo State, Ipeúna, rio Passa Cinco, upper rio Paraná basin. Parodon pongoensis: MNRJ 11756, 03, 95.296.4 mm SL + 01 c\&s, 90.3 mm SL, Brazil, Goiás State, Formosa, rio Água Quente, tributary of rio Paranã, rio Tocantins basin. USNM 261400, 01 c\&s, 44.1 mm SL, Peru, Ucayali, Pucallpa, río Ucayali, río Ucayali basin. Parodon suborbitalis: IAvH 0032, 07, 71.3-125.7 mm SL, + 01 c\&s, 118.6 mm SL, Colombia, Guajira, río Rancheria, atlantic coastal drainage. MBUCV-V 14569, 04 de 24, 35.6-47.6 mm SL, + 01 c\&s, 36.1 mm SL, Venezuela, Zulia, Qda. Puerta El Hacha, lake Maracaibo basin. MCNG 15792, 20, 24.6-34.2 mm SL, + 02 c\&s, A: 31.0 mm, B: 30.8 mm SL, Venezuela, Portuguesa, Guanare, río Portuguesa, río Apure drainage, río Orinoco basin. Saccodon dariensis: IAvH 
2717, 03, 33.6-43.3 mm SL, + 01 c\&s, $44.1 \mathrm{~mm} \mathrm{SL}$, dental form type II (Roberts, 1974a), Colombia, Guajira, arroyo Tabaco, atlantic coastal drainage. USNM 208503, 04 c\&s, A1: 100.8 mm, A2: 88.7 mm, B: near 80.0 mm, C: $96.2 \mathrm{~mm} \mathrm{SL}$, dental form type I and IV (Roberts, 1974a), Panama, Panama, río Sabalo, tributary of upper río Bayano, pacific coastal drainage. Saccodon terminalis: CAS 222676, 03, 42.8-37.4 mm SL + 01 c\&s, 35.6 mm SL, dental form type II (Roberts, 1974a), Ecuador, Los Rios, río Vinces, río Daule basin, pacific coastal drainage. Saccodon wagneri: MZUSP 20254, 04, 58.2-65.0 mm SL, + 01 c\&s, $58.1 \mathrm{~mm} \mathrm{SL}$, dental form type IV (Roberts, 1974a), Ecuador, Los Rios, Montalvo, Arroyo Bambine, affluent of rio Crystal, pacific coastal drainage. MZUSP 20255, 03, 47.9-53.0 mm SL, same data as anterior. Distichodontidae. Xenocharax spilurus: AMNH 230302, 01 of 78, 106.7 mm SL, + 01 c\&s, 99.9 mm SL, Gabon, Moyen-ogooue, Lake Zile, Ogooué river basin. Curimatidae. Cyphocharax gilbert: MNRJ 12845, 12, 39.1-105.9 mm SL, + 02 c\&s, A: 46.9 mm, B: 51.3 mm SL, Brazil, Rio de Janeiro, Campos dos Goytacazes, lagoa Verde, rio Paraíba do Sul basin. Steindachnerina insculpta: MNRJ 27587, 14, 104.1-131.8 mm SL, + 02 c\&s, A: 110.7 mm, B: 109.1 mm SL, Brazil, São Paulo, Canitar, mouth of Ribeirão Santo Antônio, tributary of rio Paranapanema, upper rio Paraná basin. Anostomidae. Schizodon knerii: MNRJ 15867, 06, 111.9-120.6 mm SL, + 01 c\&s, 115.3 mm SL, Brazil, Minas Gerais, Manga, rio São Francisco, rio São Francisco basin. Crenuchidae. Characidium sp. aff. C. alipioi: MNRJ 22643, 57, 49.1-81.7 mm SL, + 02 c\&s, A: 66.1 mm, B: 69.9 mm SL, Brazil, São Paulo, Pindamonhangaba, Ribeirão dos Buenos or Ribeirão dos Moreiras, rio Paraíba do Sul basin. Crenuchus spilurus: MNRJ 22106, 14, 23.5-34.0 mm SL, + 01 c\&s, 31. mm SL, Brazil, Pará, Aveiro, Igarapé Açu, rio Tapajós basin. Hemiodontidae. Hemiodus ternetzi: MNRJ 13038, 74, 49.9-97.9 mm SL, + 02 c\&s, A: 55.6 mm, B: 61.7 mm SL, Brazil, Goiás, Minaçu, tributary of Córrego Lageado, rio Tocantins basin. Alestiidae. Brycinus lateralis: MNRJ 13407, 08, 33.1-100.0 mm SL, + 02 c\&s, A: $40.5 \mathrm{~mm}$, B: $65.2 \mathrm{~mm}$ SL, Botswana, Okavango river basin. Chalceus erythrurus: MZUSP 6707, 04 of 33, 107.9-123.9 mm SL, + 02 c\&s, A: 120.0 mm, B: 117.8 mm SL, Brazil, Amazonas, Manaus, rio Negro, rio Negro basin. Hydrocynus vittatus: MNRJ 13412, 03, 99.4-115.4 mm SL, + 01 c\&s, 87.6 mm SL, Namibia, Matave, Okavango river basin. Characidae. Astyanax rivularis: MNRJ 28003, 202, 12.5-76.9 mm SL, + 02 c\&s, A: 63.8 mm, B: 55.2 mm SL, Brazil, Minas Gerais, Piumhi, rio Araras, rio São Francisco basin. Brycon orthotaenia: MNRJ 14226, 04, 102.1112.1 mm SL, + 01 c\&s, 84.6 mm SL, Brazil, Minas Gerais, Manga, rio Mocambinho, rio São Francisco basin. Phenacogaster franciscoensis: MNRJ 14206, 24, 13.1-37.6 mm SL, + 02 c\&s, A: $39.1 \mathrm{~mm}$, B: $36.0 \mathrm{~mm}$ SL, Brazil, Minas Gerais, Montes Claros, rio Verde Grande, rio São Francisco basin. Cynodontidae. Acestrorhynchus lacustris: MNRJ 26251, 13, 120.2-172.0 mm SL, + 01 c\&s, 137.0 mm SL, Brazil, Goiás, Paracatu, rio São Marcos, tributary of Rio Paranaíba, upper rio Paraná basin. Erythrinidae. Hepsetus odoe: MNRJ 13405, 01, 115.7 mm SL, + 01 c\&s, 123.0 mm SL, Botswana, Matlapenang, Okavango river basin. Hoplias malabaricus: MNRJ 14133, 25, 20.5-55.3 mm SL, + 03 c\&s, A: 51.7 mm, B: 35.4 mm, C: 35.9 mm SL, Brazil, Rio de Janeiro, Silva Jardim, Lagoa de Juturnaíba, rio São João basin, atlantic coastal drainage. Lebiasina bimaculata: MZUSP 80085, 08 of 78, 42.6-58.0 mm SL, + 02 c\&s, A: 59.5 mm, B: 69.4 mm SL, Peru, Cajamarca, rio Jequetepeque, rio Chilete basin, pacific coastal drainage.

\section{Acknowledgements}

For the loan of specimens and other assistance during visits to their institutions, we are indebted to John Lundberg, Mark Sabaj and Mariangeles Arce (ANSP), Scott Schaefer, Melanie Stiassny, Barbara Brown, and Radford Arrindell (AMNH), David Catania and Carl Ferraris (CAS), Mary Anne Rogers (FMNH), Javier Maldonado-Ocampo (IAvH), Lúcia H. Rapp Py-Daniel (INPA); Donald Taphorn (MCNG), Zilda Margarete S. Lucena and Carlos A. S. Lucena (MCP), Vinícius Abilhoa (MHNCI), Osvaldo Oyakawa (MZUSP), and Richard Vari, Jeff Williams, and Sandra Raredon (USNM). Thanks are due to Carlos do Nascimiento and Nadia Milani (MBUCV-V) for taking pictures of the holotype, and Sandra Raredon, David de Santana and Vinícius A. Bertaco (USNM) for kindly taking pictures and Xrays of non-type specimens. The authors are thankful to an anonymous reviewer for suggestions for the improvement of the manuscript. Support for museum studies associated with this paper were partially provided by Coordenação de Aperfeiçoamento de Pessoal de Nível Superior (CAPES, doctoral fellowship to LFSI; and post-doctoral fellowship to CSP), Conselho Nacional de Desenvolvimento Científico e Tecnológico (CNPq, 474788/2006-7 and 502975/2005-9 to MNRJ; 350672/2011-3, post-doctoral -DCR- fellowship to LFSI; and 308556/2009-7 post-doctoral fellowship to CSP), and Fundação de Amparo à Pesquisa do Espírito Santo (FAPES, 53132203/ 2011, post-doctoral -DCR- fellowship to LFSI).

\section{Literature Cited}

Bonilla, A., A. Machado-Allison, C. Silvera, B. Chernoff, H. López \& C. Lasso. 1999. Apareiodon orinocensis, una nueva especie de pez de agua dulce (Pisces: Characiformes: Parodontidae) proveniente de los Rios Caura y Orinoco, Venezuela. Acta Biologica Venezuelica, 19: 1-10.

Eigenmann, C. H. 1916. On Apareiodon, a new genus of characid fishes. Annals of the Carnegie Museum, 10: 71-76.

Fricke, R. \& W. N. Eschmeyer. 2011. A guide to the fish collections on the Catalogue of Fishes database. http://research.calacademy.org/ redirect?url=http://researcharchive.calacademy.org/research/ Ichthyology/catalog/collections.asp. Accessed August 19, 2011.

Ingenito, L. F. S. 2008. Análise filogenética da família Parodontidae (Teleostei, Characiformes). Unpublished Ph.D. Dissertation, Museu Nacional, Universidade Federal do Rio de Janeiro, Rio de Janeiro, 127p.

Ingenito, L. F. S. \& P. A. Buckup. 2005. A new species of Parodon from the Serra da Mantiqueira, Brazil (Teleostei: Characiformes: Parodontidae). Copeia, 2005: 765-771.

Londoño-Burbano, A., C. Román-Valencia \& D. C. Taphorn. 2011. Taxonomic review of Colombian Parodon (Characiformes: Parodontidae), with description of three new species. Neotropical Ichthyology, 9: 709-730.

Pavanelli, C. S. 1999. Revisão taxonômica da família Parodontidae (Ostariophysi: Characiformes). Unpublished Ph.D. Dissertation, Universidade Federal de São Carlos, São Carlos, 332p.

Pavanelli, C. S. 2006. New species od Apareiodon (Teleostei: Characiformes: Parodontidae) from the Rio Piquiri, upper rio Paraná basin, Brazil. Copeia, 2006: 89-95. 
Pavanelli, C. S. 2003. Family Parodontidae (Parodontids). Pp. 4650. In: Reis, R. E, S. O. Kullander \& C. J. Ferraris Jr. (Eds.). Check list of the freshwater fishes of South and Central America. Porto Alegre, Edipucrs, 729p.

Pavanelli, C. S. \& H. A. Britski. 2003. Apareiodon Eigenmann, 1916 (Teleostei, Characiformes), from the Tocantins-Araguaia Basin, with description of three new species. Copeia, 2003: 337-348.

Potthoff, T. 1984. Clearing and staining techniques. Pp. 35-37. In: Moser, H. G., W. J. Richards, D. M. Cohen, M. P. Fahay, A. W. Kendall Jr. \& S. L. Richardson (Eds.). Ontogeny and systematics of fishes. American Society of Ichthyologists and Herpetologists, Special Publication Number 1. Lawrence, Allen Press, 760p.

Roberts, T. R. 1974a. Dental polimorphism and systematics in Saccodon, a Neotropical genus of freshwater fishes (Parodontidae, Characoidei). Journal of Zoology, 173: 303-321.

Roberts, T. R. 1974b. Osteology and classification of the Neotropical characoid fishes of the families Hemiodontidae (including Anodontidae) and Parodontidae. Bulletim of the Museum of Comparative Zoology, 146: 411-472.

Schultze, H.-P. \& G. Arratia. 1989. The composition of the caudal skeleton of teleosts (Actinopterygii: Osteichthyes). Zoological Journal of the Linnean Society, 97: 189-231.

Taphorn, D. C., H. Lopez-Fernandez \& C. R. Bernard. 2008. Apareiodon agmatos, a new species from upper Mazaruni river, Guyana (Teleostei: Characiformes: Parodontidae). Zootaxa, 1925: 31-38.

Vari, R. P., C. J. Ferraris, A. Radosavljevic \& V. A. Funk. (Eds.). 2009. Checklist of the freshwater fishes of the Guiana Shield. Bulletin of the Biological Society of Washington, 17: 1-93.

Submitted February 24, 2012

Accepted August 15, 2012

Published September 28, 2012 